\title{
siry
}

Open access Journal

International Journal of Emerging Trends in Science and Technology

DOI: https://dx.doi.org/10.18535/ijetst/v7i5.01

\section{The Effect of the Ex-Smoker as an Educator on Smoking Behaviour and Vital Lung Capacity of the Suspect Lung Cancer Patients}

\author{
Authors \\ Lucky Herawati ${ }^{1}$, Jenita Doli Tine Donsu ${ }^{2}$, Muh Kayani Raftaz ${ }^{3}$, \\ Malik Muhammad Ali Awan ${ }^{4}$ \\ ${ }^{1,2}$ Polytechnic of Health, Ministry of Health Yogyakarta Indonesia \\ ${ }^{3}$ Cancer Volunteer and Leader of the "Kiran" Cancer Foundation in Islamabad Pakistan \\ ${ }^{4}$ Isra University- Islamabad, Pakistan \\ *Corresponding Author \\ Lucky Herawati \\ Polytechnic of Health, Ministry of Health Yogyakarta Indonesia Republic \\ Address: Tatabumi Street, Number 3, Banyuraden, Gamping, Sleman, postcode 55293

\begin{abstract}
The study is aimed at getting information the effect of the ex-smoker as an educator on smoking behaviour and the lung vital capacity of the suspect lung cancer patients.

The study design is quasi experiment. Respondents of the research are 45 suspect lung cancer patients taken from 4 hospitals. The data are analysed by parametric and nonparametric, level of significant 0.05. The result showed the ex-smoker as an educator able to increase the knowledge score, to decrease the average number of cigarettes smoked per-day and to increasethe vital lung capacity, significantly.

Keywords: educator; smoking behaviour; suspect lung cancer patients.
\end{abstract}

\section{Introduction}

Tobacco product is predicted to be responsible to 3 million mortality every year in the world or approximately $6 \%$ of all mortality in the world. In the year of 2020 or early 2030s, tobacco product will be predicted as the cause of $17.7 \%$ of all mortality in the developed countries and $10.9 \%$ of all mortality in the developing countries including Indonesia and Pakistan. The relation between tobacco and disease was, the tobacco cause approximately 25 diseases including cancer (Raoul A. Walsh; Rob W. Sanson-Fisher, 2001). Recently, along with studies reporting the effect of urban environments on various kinds of diseases such as cancers, academic interest in health improvement through urban planning and developing related policies has been growing (Haejung CHUN, 2020).

Smoking behaviour contributes to growth and spread cancer faster earlier and contributes to 80-
90\% lungs cancer evidence (Eldridge, 2018). According to Eldridge L (2018), smoking behaviour together with other factor, was cofactor of cancer disease. Lungs cancer are one of the cancer diseases (Eldridge, 2018). There are $40-51 \%$ of the smokers who have lungs cancer diagnose still continue smoking (Chia-Chen YANG, Chien-Ying LIU, Kwua-Yun WANG, Fur-Hsing WEN, Yu-Chin LEE, 2019)(Berg, Carla J; Thomas, Akilah N; Mertens, Ann C; Schauer, Gillian L; Pinsker, Erika A; Ahluwalia, Jasjit S; Khuri, 2013). Cigarette smoking is established as the primary cause of lung cancer linked to about $50 \%$ of lung cancer death in women and $75 \%$ in men worldwide (Rebecca H. Lehto, 2019). Based on that data, it is important to change the smoking behaviour of the suspect lung patients in order not to fall in the lung cancer disease severity. 
Health Department such as in Indonesia Republic have provided the lung patient the facility such as the quit tobacco unit in some hospitals. The lung patient smokers were seldom used this facility to consult how to stop smoking. Some researchers offered them some programs such as provide them a private consultation by phone facility (Davidson, SM; Boldt, RG; Louiie, 2018), gave them an information about the risk of smoking behaviour and the benefit of stop smoking (Dimitra Kale, Hazel Gilbert, 2019)(Mc Bride, Colleen; Halabi, Susan; Bepler, Gerold; Lyna, Pauline; Mc Intyre, Lauren; Lipkus, Isaac; Albright, 2000)(Simmons, Vani Nath; Litvin, Erika B; Patel, Riddhi D; Jacobson, Paul B; McCaffrey, Judith C; Bepler, Gerold; Quinn, Gwendolyn P; Brandon, 2009), and provided them the therapy nicotine (Turner, R.C; Lucke-World, P.P; Hwang, R \& Underwood, 2016)(Underwood et al., 2017). Davidson (2018) stated that, $13 \%$ of the patients who diagnosed lung cancer, accepted those programs and just 3\% participated into the programs (Davidson, SM; Boldt, RG; Louiie, 2018).

This study was aimed at preventing the suspect lung cancer patient smoker not to the fall into the severity disease. On the other side, there were some ex-smoker who successful stop smoking. Therefore, this study tries to give a role to the exsmokers as an educator on smoking behaviour of the suspect lung cancer patients.

\section{Method}

The study design was quasi experiment, pre-test and post-test with control group design. We used 2 intervention groups and a control group. The respondents were the smoker men whose suspect lung cancer patients. They were recommended by the doctor. The number of the respondents were 45 (Jacob Cohen, 1988) taken by accidental sampling from 4 hospitals. The 30 respondents were taken from 3 hospitals (PR, Bet, Res) in Indonesia. They were placed in 2 intervention groups $\left(X_{1}\right.$ and $X_{2}$ intervention groups). The 15 respondents were taken from "I" hospital in
Islamabad Pakistan. They were placed in the control group.

Independent variable was the presence of the exsmoker as an educators. The educators did their activities in $X_{1}$ and $X_{2}$ intervention groups. The respondents of the $X_{1}$ group received a booklet in order they can read it at home but the respondents of the $\mathrm{X}_{2}$ group didn't receive it. The respondents of the control group didn't get anything whether the ex-smoker an educator or booklet. The dependents variables were smoking behaviour. It consists of 1) knowledge about cigarettes and its danger, 2) number of cigarettes smoke per day. The other dependent variable was the lung vital capacity of the respondents. These dependents variables were measured twice (before and after intervention). The knowledge was measured by using a test. The test consisted of 17 items and its score of reliability was 0.84 . The number of cigarettes smoked per day was measured by using a form that attached in the booklet, and the lung vital capacity was measured by using spirometer tool.

The kind of educators' activities were such as giving information about the risk of smoking and the benefit of non-smoking, sharing their experiences how to stop smoking, encouraging them to reduce the number of cigarettes smoked per-day, and discussing their problem in smoking and find the solution. The educator did their activities three times in 3 months. They had to meet the respondent one by one. Their first meeting was held at the hospital, because the respondent had to check his vital lung capacity (pre-test). Their second meeting was held whether at the hospital or at the respondent's home. It depends on their agreement. Their third meeting was held at the hospital, because the respondent had to check his vital lung capacity (post-test). The distance between one to another meetings was 1 or 2 weeks.

The educators were the ex-smokers who successfully stopped smoking and agree to share their experiences how to stop smoking. We used 6 educators. They had smoked for 30 years in 
average at the past and have stopped smoking at least 3 years whether relapse or not. Their age was 57 years old in average and half of them have Master degree education. They have variety in job namely civil servants, retired man, and the employed based on contract. They followed the technical meeting before they done in order to have equal perception of their role.

The booklet consisted of 3 parts, namely: 1) information about the risk of smoking relation with the lung cancer disease and the benefit if they stopped smoking, 2) the ex-smoker's unique story how to stop smoking, and 3) the calendar monitoring, that respondent have to record the number of cigarettes smoked per-day.

Data were analysed by parametric test (Analysis of variance, Multivariate Analysis of variance, and Multivariate Analysis of covariance) and nonparametric statistic (Kruskal Wallis and Friedman test). The level of significant was 0.05 . This study run on May-November 2019. The respondents submitted the inform consent to the researcher team before they participate into the research. This study had an Ethical Approval from the Ethic Commission on Health of Polytechnic of health of
Ministry of health Yogyakarta Indonesia, Number e-KEPK/ POLKESYO/ 0082/v/ 2019, on May 28, 2019.

\section{Result and Discussion}

Characteristic of the respondents consisted of their age, length of smoking, level of education, job, the preference cigarettes they smoked, and the presence of the family member who smoke at home.The mean age of them was 49 and the mean length of their smoking was 27 years. The most of their educational level was senior high school and the most of their job was entrepreneur. Most of them smoked filter cigarettes and stated that no family member smoking at home. There were the same characteristic between respondents in three groups before intervention significantly ( $p$ value $>0.05$ ) except the level of education and the job ( $p$ value <0.05). Although the respondents came from different hospital and country, the characteristic was alike. Probably, the last two characteristics that mention before bothered the result of the study. They will be controlled by data analysed. The table 1 provides more information about the characteristic of respondents.

Table 1 Characteristics of Respondents

\begin{tabular}{|c|c|c|c|c|c|c|c|c|c|}
\hline \multirow[t]{2}{*}{ Variables } & \multicolumn{2}{|c|}{$\begin{array}{c}\mathrm{X} 1 \\
(\mathrm{n}=15) \\
\end{array}$} & \multicolumn{2}{|c|}{$\begin{array}{c}\mathrm{X} 2 \\
(\mathrm{n}=15)\end{array}$} & \multicolumn{2}{|c|}{$\begin{array}{c}\mathrm{K} \\
(\mathrm{n}=15)\end{array}$} & \multicolumn{2}{|c|}{ Total $(\mathrm{n}=45)$} & \multirow[t]{2}{*}{ pvalue $\mathrm{a}^{\mathrm{a}}$} \\
\hline & Mean & SD & Mean & SD & Mean & SD & Mean & SD & \\
\hline The age (year) & 48,1 & 13.7 & 49.8 & 10.5 & 48.2 & 17.3 & 48.7 & 13.8 & 0.938 \\
\hline Length of smoking (year) & 26.20 & 12.3 & 30.4 & 8.0 & 25.1 & 17.3 & 27.2 & 13.0 & 0.517 \\
\hline Variables & $\mathrm{F}$ & $\%$ & $\mathrm{~F}$ & $\%$ & $\mathrm{~F}$ & $\%$ & $\mathrm{~F}$ & $\%$ & .pvalue ${ }^{b}$ \\
\hline \multicolumn{10}{|l|}{ Level of education: } \\
\hline ElementaryS & 1 & 6.7 & 1 & 6.7 & 7 & 46.7 & 9 & 20.0 & \multirow[t]{6}{*}{$0.000^{*}$} \\
\hline Junior High S & 3 & 20.0 & 2 & 13.3 & 6 & 40.0 & 11 & 24.4 & \\
\hline Senior High S & 10 & 66.7 & 5 & 33.3 & 2 & 13.3 & 17 & 37.8 & \\
\hline Bachelor & 1 & 6.7 & 3 & 20.0 & 0 & 0 & 4 & 8.9 & \\
\hline Graduate & 0 & 0 & 3 & 20.0 & 0 & 0 & 3 & 6.7 & \\
\hline Postgraduate & 0 & 0 & 1 & 6.7 & 0 & 0 & 1 & 2.2 & \\
\hline \multicolumn{10}{|l|}{ Job: } \\
\hline Civil servant & 0 & 0 & 1 & 6.7 & 1 & 6.7 & 2 & 4.4 & \multirow[t]{7}{*}{$0.036^{*}$} \\
\hline Armed Forced & 0 & 0 & 0 & 0 & 1 & 6.7 & 1 & 2.2 & \\
\hline Entrepreneur & 4 & 26.7 & 7 & 46.7 & 0 & 0 & 11 & 24.4 & \\
\hline Retired & 4 & 26.7 & 4 & 26.7 & 1 & 6.7 & 9 & 20.0 & \\
\hline Private employment & 1 & 6.7 & 2 & 13.3 & 7 & 46.7 & 10 & 22.2 & \\
\hline Laborers & 2 & 13.3 & 0 & 0 & 5 & 33.3 & 7 & 15.0 & \\
\hline Others & 4 & 26.7 & 1 & 6.7 & 0 & 0 & 5 & 11.1 & \\
\hline \multicolumn{10}{|l|}{ Type of cigarettes: } \\
\hline Filter & 13 & 86.7 & 14 & 93.3 & 15 & 100 & 42 & 93.3 & \multirow[t]{2}{*}{0.351} \\
\hline Kretek & 2 & 13.3 & 1 & 6.7 & 0 & 0 & 3 & 6.7 & \\
\hline \multicolumn{10}{|c|}{ Family member smoking at home: } \\
\hline No one & 9 & 60.0 & 13 & 86.7 & 7 & 46.7 & 29 & 64.4 & \multirow[t]{3}{*}{0.118} \\
\hline 1 person & 5 & 33.3 & 1 & 6.7 & 8 & 53.3 & 14 & 31.1 & \\
\hline 2 persons & 1 & 6.7 & 1 & 6.7 & 0 & 0 & 2 & 4.4 & \\
\hline
\end{tabular}

Note: $\mathrm{X} 1=$ educator plus booklet; $\mathrm{X} 2=$ educator minus booklet; $\mathrm{K}=\mathrm{No}$ intervention. ${ }^{\mathrm{a} A n a l y s i s}$ of variance test; ${ }^{\mathrm{b}} \mathrm{KruskalWallis}$ test; ${ }^{*}$ Level of significant 0.05 


\section{The Knowledge of Respondents}

The knowledge of respondent was measured using a test. This test consisted of 17 items and the maximum score was 17 . Before intervention, the mean score of their knowledge was 10.40 and after intervention became 11.60 or $68.23 \%$ of the maximum score. The increasing number of the knowledge was $11.54 \%$. The result showed that the respondent in the $\mathrm{X}_{1}$ group had higher score of knowledge than $X_{2}$ and the control groups. It was statistically different whether before and after adjusting for level of education and the job ( $p$ value 0.012 and 0.017 ). It means that the level of education and the job were not annoying the process of intervention. So, the intervention especially the ex-smoker as an educator plus booklet was able to increase the score of knowledge about smoking and its dangers. The table 2 below provides this information in detail.

Table 2 The Knowledge of Respondents

\begin{tabular}{|c|c|c|c|c|c|c|c|c|}
\hline \multirow[t]{2}{*}{ Groups } & \multicolumn{2}{|c|}{ Pre-test } & \multicolumn{2}{|c|}{ Post-test } & \multicolumn{2}{|c|}{ Gain Score } & pvalue $^{\mathrm{a}}$ & .pvalue $^{\mathrm{b}}$ \\
\hline & $\begin{array}{c}\text { Mean } \pm \\
\text { SD }\end{array}$ & $\begin{array}{l}\text { Min- } \\
\text { Max }\end{array}$ & $\begin{array}{l}\text { Mean } \pm \\
\text { SD }\end{array}$ & $\begin{array}{l}\text { Min- } \\
\text { Max }\end{array}$ & $\begin{array}{l}\text { Mean } \pm \\
\text { SD }\end{array}$ & $\begin{array}{l}\text { Min- } \\
\text { Max }\end{array}$ & & \\
\hline$X 1(n=15)$ & $\begin{array}{c}1.13 \pm \\
1.80 \\
\end{array}$ & $\begin{array}{c}7 \mathrm{~s} / \mathrm{d} \\
14 \\
\end{array}$ & $\begin{array}{c}13.20 \pm \\
1.85 \\
\end{array}$ & $\begin{array}{c}10 \mathrm{~s} / \mathrm{d} \\
15\end{array}$ & $\begin{array}{c}2.07 \pm \\
1.87\end{array}$ & $0 \mathrm{~s} / \mathrm{d} 5$ & $0.017^{*}$ & $0.012^{*}$ \\
\hline$X 2(n=15)$ & $\begin{array}{c}9.73 \pm \\
2.28\end{array}$ & $\begin{array}{c}7 \mathrm{~s} / \mathrm{d} \\
15\end{array}$ & $\begin{array}{c}11.60 \pm \\
2.06\end{array}$ & $\begin{array}{c}7 \mathrm{~s} / \mathrm{d} \\
14\end{array}$ & $\begin{array}{c}1.87 \pm 2.4 \\
1\end{array}$ & -4 s/d 5 & & \\
\hline $\mathrm{K}(\mathrm{n}=15)$ & $\begin{array}{c}10.33 \pm \\
2.49\end{array}$ & $\begin{array}{c}5 \mathrm{~s} / \mathrm{d} \\
14\end{array}$ & $\begin{array}{c}10.00 \pm \\
2.82\end{array}$ & $\begin{array}{c}5 \mathrm{~s} / \mathrm{d} \\
14\end{array}$ & $\begin{array}{c}-0.33 \pm \\
2.92\end{array}$ & $-5 \mathrm{~s} / \mathrm{d} 3$ & & \\
\hline $\begin{array}{l}\text { Total } \\
(\mathrm{n}=45)\end{array}$ & $\begin{array}{c}10.40 \pm \\
2.24\end{array}$ & $\begin{array}{c}5 \mathrm{~s} / \mathrm{d} \\
15\end{array}$ & $\begin{array}{c}11.60 \pm \\
2.59\end{array}$ & $\begin{array}{c}5 \mathrm{~s} / \mathrm{d} \\
15\end{array}$ & $\begin{array}{l}1.20 \pm \\
2.62\end{array}$ & $-5 \mathrm{~s} / \mathrm{d} 5$ & & \\
\hline
\end{tabular}

Note: $\mathrm{X} 1=$ educator plus booklet; $\mathrm{X} 2=$ educator minus booklet; K= No intervention; $\mathrm{SD}=\mathrm{Standard}$ Deviation; ${ }^{\mathrm{a}}$ Multivariate of analysis variance Test; ${ }^{\mathrm{b}}$ Multivariate of covariance analysis test; * Level of significant 0.05

The $\mathrm{X}_{1}$ intervention group was better than the other group. The first reason was the activity of the educators. One of their activities was giving information about the benefit and negative impact of smoking. They did it three times in the study period. In addition, the respondents had a booklet that they could read it at home. There was information about relationship between smoking and cancer disease in the booklet. The other reason was a similar characteristic between the respondent and the educators. Although the educator smoked at the past and the respondent was still active smoking, they had an experience in smoking. The similar characteristic between them was increasing their communication effectively. This condition was in line with two recently research. The first research was a review research about group-based interventions that use peers as educators or group facilitators (Ramchand et al., 2017). It stated that commonly they improved knowledge, attitudes, beliefs, and perception. The second formally research was an experimental research, compared peer education and classic training method (Ayaz and Açıl,
2015). In the peer education group indicated the increasing mean score of knowledge significantly different than the other. Look on the other side, that counselling factors are predicted to delay treatment in lung cancer patients at risk of surgery (Oswalda, M.K.; Halle-Smithb, J; Mehdic, R; Nightingaled, P; Naidua, 2019).

Although the ex-smoker as an educator was able to increase the score of knowledge, this result didn't get an optimal knowledge. We used a test to measure the knowledge of respondents. This test consisted of 17 items and the maximum score was 17. After intervention, the mean score of their knowledge became 11.60 or $68.23 \%$ of the maximum score. This score indicated the suboptimal score. This condition was in line with the knowledge of the patients at a perinatal substances abuse treatment centre. They had suboptimal knowledge of the smoking risk after intervention (Chisolm et al., 2010).

\section{The number of cigarettes smoked per-day}

The $X_{1}$ experiment group had a higher decreasing number of cigarettes smoked per-day than the $\mathrm{X}_{2}$ 
experiment and the non-intervention one. The $\mathrm{X}_{1}$ intervention group was able to decrease the average number of cigarettes smoked per-day from 12 cigarettes became 8 cigarettes or decreasing $33.33 \%$. The data of decreasing number of cigarettes smoked per-day didn't show normal distribution. So, we used non-parametric statistics to analysis it. The result of the statistics analysis showed the different number of cigarettes smoked per-day in 3 groups significantly ( $\mathrm{p}$ value 0.0001 ). It means that the $X_{1}$ intervention was the best intervention to decrease the number of cigarettes smoked per-day. Table 3 below shows the detail information.

Table 3 Decreasing number of cigarettes smoked per-day

\begin{tabular}{|l|c|c|c|c|c|c|c|}
\hline \multirow{2}{*}{ Groups } & \multicolumn{2}{|c|}{ Pre-test } & \multicolumn{2}{c|}{ Post-test } & \multicolumn{2}{c|}{ GainScore } & .pvalue $^{\text {a }}$ \\
\cline { 2 - 7 } & Mean & SD & Mean & SD & Mean & SD & \\
\hline X1 & 9.27 & 3.75 & 5.07 & 2.52 & 4.20 & 2.93 & \multirow{2}{*}{$0.0001^{*}$} \\
\hline X2 & 11.93 & 5.8 & 6.00 & 1.92 & 5.93 & 4.65 & \\
\hline K & 13.60 & 7.46 & 13.60 & 7.46 & 0.00 & 0 & \\
\hline Total & 11.60 & 6.03 & 8.22 & 5.98 & 3.38 & 3.99 & \\
\hline
\end{tabular}

Note: $\mathrm{X} 1=$ educator plus booklet; $\mathrm{X} 2=$ educator minus booklet; $\mathrm{K}=$ No intervention; $\mathrm{SD}=\mathrm{Standard}$ Deviation; ${ }^{\mathrm{a}}$ Friedman Test; $*$ Level of significant 0.05

There were 3 reasons to explain this condition. The first was the role of recording form in the booklet. The respondents in the $\mathrm{X}_{1}$ group had to record the number of cigarettes smoked per day. Maybe they were shame if the number of cigarettes still the same with the number of cigarettes before. This condition pressed them to smoke a little number of cigarettes per day. The second reason was the favourable individual meeting between the educator and the respondent. There was a discussion between them. The situation of the discussion was more favourable compare to the consultation. They could spoke everything related to the smoking behaviour and how to quit tobacco. The condition of the discussion was very closely. The respondent felt getting privacy. Dimitra Kale (2019) stated that this situation was one of the 7 constraints in the lack efficacy of the stop smoking services (Dimitra Kale, Hazel Gilbert, 2019). Based on the observation at the quit tobacco consultation unit in "Res" hospital in Indonesia, there were lack of patients who used this facility. The staff of the unit were young women who hadn't smoked yet. The other side, most of the lung patients were the old men. Maybe, the patient didn't realize the favourable situation. The third reason was the role of the stories in the booklet. The $\mathrm{X}_{1}$ respondents received a booklet. They were able to read it at home. The story was unique stories compiled of the ex-smoker experiences how to quit tobacco. The stories might be interesting to be followed.

Although this study successful to reduce the number of cigarettes smoked per day, this study wasn't in line with the intervention done by Lindson-Hawley N, et al (2016). Their intervention were types of behavioural advice. The result showed that the intervention is inadequate to support for reducing smoking of the smokers with no immediate desire to quit all tobacco use (Lindson-Hawley N, HartmannBoyce J, Fanshawe TR, Begh R, Farley A, 2016). In those article, we didn't find the description of the advisor's characteristic. Maybe, they had different characteristic between the advisor and the smokers. So, the smoker hesitated to make consultation to advisor.

\section{The Lung Vital Capacity}

In this study, we measure the forced vital capacity (FVC) to describe the lung vital capacity. The intervention had increased the lung vital capacity (\%) from $69.06 \%$ became $85.14 \%$ or increasing $19.47 \%$. The gain score of lungs vital capacity in the $\mathrm{X}_{1}$ group was higher than the $\mathrm{X}_{2}$ and the nonintervention groups. Multivariate analysis showed that there was statistically different score of the lungvital capacity between three groups whether adjusted for the level of education and the jobs or not ( $p$ value 0.0001 and $p$ value 0.0001 ). This result indicated that the education and the job 
weren't annoying the result of this study. The intervention especially the $\mathrm{X}_{1}$ group had a great impact in increasing the lungs vital capacity of the respondents. The table 4below shows more information about it.

Table 4 Lungs vital Capacity (\%)

\begin{tabular}{|c|c|c|c|c|c|c|c|c|}
\hline Group & \multicolumn{2}{|c|}{ Pre-test } & \multicolumn{2}{|c|}{ Post-test } & \multicolumn{2}{|c|}{ Gain Score } &.$p v^{a}$ &.$p v^{b}$ \\
\hline & $\begin{array}{c}\text { Mean } \pm \text { SD } \\
\%\end{array}$ & Min-Max & $\begin{array}{c}\text { Mean } \pm \\
\%\end{array}$ & Min-Max & $\begin{array}{c}\text { Mean } \pm \\
\%\end{array}$ & Min-Max & & \\
\hline $\mathrm{X} 1(\mathrm{n}=15)$ & $69.06 \pm 18.4$ & $\begin{array}{c}42.90 \mathrm{~s} / \mathrm{d} \\
110\end{array}$ & $\begin{array}{c}85.14 \pm 16 \\
.7\end{array}$ & $\begin{array}{c}59.96 \\
\text { s/d121.4 }\end{array}$ & $\begin{array}{c}19.47 \pm 16 \\
.0\end{array}$ & $\begin{array}{c}-0.90 \mathrm{~s} / \mathrm{d} \\
56.40\end{array}$ & & \\
\hline $\mathrm{X} 2(\mathrm{n}=15)$ & $61.97 \pm 10.5$ & $\begin{array}{c}47.90 \mathrm{~s} / \mathrm{d} \\
78.69\end{array}$ & $\begin{array}{c}69.82 \pm 9 \\
7\end{array}$ & $\begin{array}{c}43.00 \mathrm{~s} / \mathrm{d} \\
80.76\end{array}$ & $\begin{array}{c}7.85 \pm \\
9.0\end{array}$ & $\begin{array}{c}-6.97 \mathrm{~s} / \mathrm{d} \\
28.03\end{array}$ & & \\
\hline $\mathrm{K}(\mathrm{n}=15)$ & $62.43 \pm 11.5$ & $\begin{array}{c}42.90 \mathrm{~s} / \mathrm{d} \\
75.80\end{array}$ & $\begin{array}{c}62.30 \pm 11 \\
.6\end{array}$ & $\begin{array}{c}42.00 \mathrm{~s} / \mathrm{d} \\
75.80\end{array}$ & $\begin{array}{c}-0.66 \pm \\
0.2\end{array}$ & $\begin{array}{c}-1.00 \mathrm{~s} / \mathrm{d} \\
0.00\end{array}$ & $0.0001^{*}$ & $0.0001^{*}$ \\
\hline Total $(n=45)$ & $64.49 \pm 14$ & $\begin{array}{c}42.90 \mathrm{~s} / \mathrm{d} \\
110.0\end{array}$ & $\begin{array}{c}72.42 \pm 15 \\
.9\end{array}$ & $\begin{array}{c}42.00 \mathrm{~s} / \mathrm{d} \\
121.4\end{array}$ & $\begin{array}{c}9.087 \pm 13 \\
.1\end{array}$ & $\begin{array}{c}-6.97 \mathrm{~s} / \mathrm{d} \\
56.40\end{array}$ & & \\
\hline
\end{tabular}

Note: $\mathrm{X} 1=$ educator plus booklet; $\mathrm{X} 2=$ educator minus booklet; $\mathrm{K}=$ No intervention; $\mathrm{SD}=\mathrm{Standard}$ Deviation; ${ }^{\mathrm{a}}$ Multivariate Analysis of variance test; ${ }^{\mathrm{b}}$ Multivariate Analysis of covariance test; ${ }^{*}$ Level of significant 0.05

The intervention especially the $\mathrm{X}_{1}$ had a great impact to increase percentage number of the lung vital capacity of the respondents. It was increasing number $19.47 \%$ in average of the vital lung capacity. On the other side, the $\mathrm{X}_{1}$ intervention also decreased the number of cigarettes $33.33 \%$ in average. There was negative correlation between increasing the vital lung capacity and decreasing number of cigarettes smoked per-day after intervention $(r=-0.363, p$ value 0.049$)$. It means that if the respondents reduce the number of cigarettes smoked per-day, the percentage number of lung capacity will increase and vice versa. Kouba et al (2015) stated that smoking habits will increase the number of inflammatory cells and alveoli damage in the lung tissue. It will accelerate the decline in lung function and the annual reduction in forced expiratory volume (FEV) was higher $(41.7 \mathrm{ml})$ than the non-smoker $(28.7 \mathrm{ml})$ and the former smoker $(38.4 \mathrm{ml})$. (Koubaa, A., Triki, M., Trabelsi, H., Masmoudi, L., Zeghal, K.N., Sahnoun, Z., Hakim, 2015). We can analysed the Kouba result that there was correlation between the forced expiratory volume with the smoking habits.

This study had limitations. The study design unrandomized although there weren't significant different characteristic between three groups. The number of cigarettes smoked per day was measured by showed the recording form that attached in the booklet. The respondents recorded it at home. We didn't know their really smoking habit.

\section{Conclusion and Recommendation}

The ex-smoker as an educator contributed to increase $11.54 \%$ of the knowledge about smoking and its dangers, to decrease $33.33 \%$ of the number of cigarettes smoked per-day, and to increase $19.47 \%$ of the lung vital capacity significantly. The research finding: the ex-smoker can be used as an educator especially for the new lung patient smoker.

This concept can be applied to other condition, for example we use the workmate or classmate as an educator. The management of the hospitals are able to use the ex-smoker who successful stopped smoking as an educator to join the quit tobacco program at the hospital.

\section{Acknowledgement}

We say thank you to Director of Health Polytechnic Ministry of Health Yogyakarta Indonesia that supported the research funding.

Conflict of Interest: There wasn't conflict of interest in this study.

\section{References}

1. Ayaz, S. and Aç1l, D. (2015) 'Comparison of Peer Education and the Classic Training Method for School Aged Children 
Regarding Smoking and its Dangers', Journal of Pediatric Nursing, 30(3), pp. e3-e12.

2. Berg, Carla J; Thomas, Akilah N; Mertens, Ann C; Schauer, Gillian L; Pinsker, Erika A; Ahluwalia, Jasjit S; Khuri, F. R. (2013) 'Correlate of continued smoking versus cessation among survivor of smokingrelated cancers', Psycho-Oncolo, 22(4), pp. 799-806.

3. Chia-Chen YANG, Chien-Ying LIU, Kwua-Yun WANG, Fur-Hsing WEN, YuChin LEE, M.-L. C. (2019) 'Smoking Status Among Patients With Newly Diagnosed Lung Cancer in Taiwan', The Journal of Nursing Research, 27(4), p. e32.

4. Chisolm, M. S. et al. (2010) 'Cigarette smoking knowledge, attitudes, and practices of patients and staff at a perinatal substance abuse treatment center', Journal of Substance Abuse Treatment, 39(3), pp. 298-305.

5. Davidson, SM; Boldt, RG; Louiie, A. (2018) 'How can we better help cancer patients quit smoking? The London Regional Cancer Program experience with smoking cessatuin', Journal Current Oncology, 25(3), pp. 226-230.

6. Dimitra Kale, Hazel Gilbert, S. S. (2019) 'An exploration of the barriers to attendance at the English Stop Smoking Services', Addictive Behaviors Reports, 9, pp. 100-141.

7. Eldridge, L. (2018) 'Smoking Related Cancers, What types of cancer are caused by smoking?', Verywell health, pp. 1-15. Available at: http://www.veriwellhealth.com/smokingrelated-cancers-2248971?utm.

8. Haejung CHUN (2020) Effects of Smoking, Drinking, and Urban Environment on Obesi-ty in Seoul, Korea, Iraian Journal of Public Health. Available at: http://ijph.tums.ac.ir/index.php/ijph/article/ view/19569.

9. Jacob Cohen (1988) Statistical Power Analysis for The Behavioral Sciences. second edi. New York: Lawrence erlbaum associates publisher. Departement of Psychology. New York University.

10. Koubaa, A., Triki, M., Trabelsi, H., Masmoudi, L., Zeghal, K.N., Sahnoun, Z., Hakim, A. (2015) 'Lung function profiles and aerobic capacity of adult cigarette and hookah smokers after 12 weeks intermittent training', Libyan Journal of Medicine, 10(10), pp. 34-40.

11. Lindson-Hawley N, Hartmann-Boyce J, Fanshawe TR, Begh R, Farley A, L. T. (2016) 'Interventions to reduce harm from continued tobacco use', Cochrane Database Syst Rev., 13(10). Available at: https://www.ncbi.nlm.nih.gov/pubmed/277 34465.

12. Mc Bride, Colleen; Halabi, Susan; Bepler, Gerold; Lyna, Pauline; Mc Intyre, Lauren; Lipkus, Isaac; Albright, J. (2000) 'Maximizing the Motivational Impact of Feedback of Lung Cancer Suceptibility on Smokers' Desire to Quit', Journal of Health Communication, 5, pp. 229-241.

13. Oswalda, M.K.; Halle-Smithb, J; Mehdic, R; Nightingaled, P; Naidua, B. A. M. T. (2019) 'Predicting Postoperative Lung Function Following Lung Cancer Resection: A Systematic Review and Meta-analysis', Elsevier Journal, 15, pp. 7-13.

14. Ramchand, R. et al. (2017) 'A systematic review of peer-supported interventions for health promotion and disease prevention', Preventive Medicine, 101, p. 156=170.

15. Raoul A. Walsh; Rob W. Sanson-Fisher (2001) 'Laerning Modules Encouraging People to Stop Smoking', Science, Behavioural Modules, Learning, pp. 1-55. Available at: file:///G:/Skema LN Pakistan/stop_smoking_whomsdmdp01_4. 
pdf.

16. Rebecca H. Lehto (2019) 'Active Smoking at the Time of A Lung Cancer Diagnosis', Asia Pacific Journal Oncology Nursing, 6(3), pp. 207-208.

17. Simmons, Vani Nath; Litvin, Erika B; Patel, Riddhi D; Jacobson, Paul B; McCaffrey, Judith C; Bepler, Gerold; Quinn, Gwendolyn P; Brandon, T. H. (2009) 'Patient-provider Communication and Prespectives on Smoking Cessation and Relapse in the Oncology Setting, Patient Education \& Counceling, 77(3), pp. 398-403.

18. Turner, R.C; Lucke-World, P.P; Hwang, R \& Underwood, B. . (2016) 'Lung cancer metastasis presenting as a solitary skull mass', Journal of Surgical Case Report, 6, pp. 1-3.

19. Underwood, J. M. et al. (2017) 'A Novel Public Health Approach to Measuring Tobacco Cessation Needs Among Cancer Survivors in Alaska', pp. 956-961. doi: 10.1007/s10900-017-0341-8. 